\title{
Simultaneous determination of Cr (III) and Cr (IV) in functional foods using liquid chromatography - inductively coupled plasma mass spectrometry (LC-ICP-MS)
}

\author{
Pham Cong Hieu', Le Van Ha ${ }^{1}$, Nguyen Minh Chau' ${ }^{1}$, Lu Thi Minh Hien ${ }^{1}$ \\ Dinh Viet Chien ${ }^{*}$, Nguyen Trung $\mathbf{H i e u}^{2}$, Nguyen Van $\mathbf{R i}^{2}$ \\ ${ }^{1}$ National Institute for Food Control, Hanoi \\ ${ }^{2}$ University of Science, Vietnam National University, Hanoi
}

(Received: 02/03/2020; Accepted: 01/06/2020)

\section{Abstract}

Chromium is often added in some functional foods to aid in the treatment of diabetes or in fortified dairy products. The toxicity of chromium depends on the oxidation state. Therefore, it is necessary to identify or quantify chromium species to assess food safety hazards. In this study, the species of Cr (III) and Cr (VI) were determined by liquid chromatography (LC) with collision cell inductively coupled plasma mass specctrophotometry (ICP-MS). The main parameters such as the concentration of complexing agents, the effect of $\mathrm{pH}$, the mobile phase flow rate, the extraction solvents as well as the extraction time and temperature were optimized. The method detection limits (MDLs) of $20 \mu \mathrm{g} / \mathrm{kg}$ for Cr (III) and $10 \mu \mathrm{g} / \mathrm{kg}$ for Cr (VI) obtained based on peak hight at mass 52 for injections at low level spiked samples. The repeatability of $\mathrm{Cr}$ (III) was $1.96 \%$ while that of $\mathrm{Cr}$ (VI) was $7.78 \%$. The recovery of $\mathrm{Cr}$ (III) and $\mathrm{Cr}$ (VI) at 1.0 $\mathrm{mg} / \mathrm{kg}$ was in the range of $88.0-103 \%$ and $89.3-96.7 \%$, respectively. The validated parameters completely met the Association of Official Analytical Collaboration (AOAC) performance requirements, which was applied to analyze $\mathrm{Cr}$ species in some functional food samples collected on the market. The content of $\mathrm{Cr}$ (III) was found in accordance with products label declaration while $\mathrm{Cr}$ (VI) was not detected.

Keywords: $C r$ (III), Cr (VI), species, functional foods, LC-ICP-MS.

\section{INTRODUCTION}

Chromium (III) is widely distributed in foods such as meat, grains, enriching in some functional foods to increase the effects of insulin and improving diabetes. Therefore, $\mathrm{Cr}$ (III) is often used to supplement foods to a certain extent, which is beneficial for the metabolism of the body. In contrast, $\mathrm{Cr}$ (VI) compounds such as chromate, bicromate and chromic acid may cause of liver and lung cancer, adversely affect health and need to be controlled [1-3]. However, there are not many researches to identify chromium species in foods, especially in functional foods. Therefore, it is necessary to determine the species of $\mathrm{Cr}$ (III) and $\mathrm{Cr}$ (VI) to give warning and recommendation to consumers.

There are many researches to the species of chromium in soil and water samples as well as kinds of common food in nature. Whereas in contrast, do not find many documents to refer for the purpose of identification and quantification of chromium species in functional foods. Previous methods often used selective extraction produres followed by analysis using UV-Vis or liquid chromatography (LC) hyphenated graphite furnace atomic absorption spectrometry (GF-AAS) system. However, these methods show limitations, such as poor sensitivity, complex 
sample treatment procedures, and time-consuming analysis. Besides, high performance liquid chromatography combined with inductively coupled plasma mass spectrometry (LC-ICP-MS) with advantages such as the low limit of detection, the high stability and accuracy, uncomplicated samples treatment, short analysis time, has been widely applied to identify chromium species on many different sample objects $[4,6,7,8]$. Moreover, in Viet Nam, there has not been published researchs on the quantification of chromium species in food supplements using LC-ICP-MS system. Therefore, in this study, LC-ICP-MS method was selected to simultaneously determine species of $\mathrm{Cr}$ (III) and $\mathrm{Cr}$ (VI) in functional foods.

\section{MATERIALS AND METHODS}

\subsection{Subject}

Some kinds of functional food samples (syrups, nuggets and capsules forms) were collected in Hanoi city to conduct researches.

\subsection{Method}

In this study, LC-ICP-MS method was applied to determine $\mathrm{Cr}$ (III) and Cr (VI) in functional foods after chromium species were extracted from samples using an ultrasonic bath.

\subsection{Experiment}

\subsubsection{Chemicals and Reagents}

All chemicals and reagents were analytical grade. The standard solutions of $\mathrm{Cr}$ (III) and Cr (VI) were purchased from Assurance Chemicals. Other chemicals such as EDTA salt, methanol, 27.5\% ammonium, 65\% nitric acid were purchased from Merck. High purity argon gas of $99.999 \%$ was from Messer. In addition, equipment standardization solutions from Perkin Elmer and cooling solutions for Chiller were also used for system operation.

\subsubsection{Instrument}

An ICP-MS system from Perkin Elmer (Model of Nexion 350X) was used in this study (Figure 1). Besides, a liquid chromatography system with an anion exchange column (5 $\mu \mathrm{m} \mathrm{x}$ $4.6 \mathrm{~mm} \times 150 \mathrm{~mm}$ ) from Hamilton was used to separate chromium species, after those were extracted from sample matrix using an ultrasonic bath (Elmer).

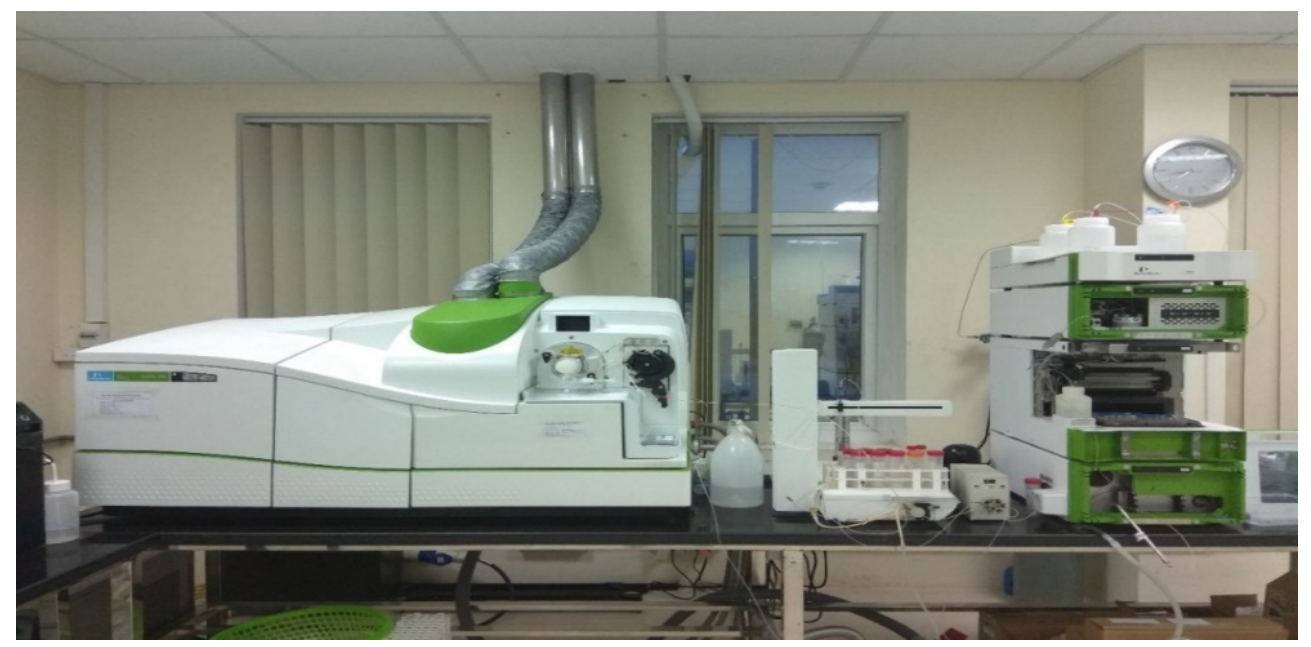

Figure 1. The ICP-MS system used in this study 


\subsubsection{Optimizing conditions for analysis of $\mathrm{Cr}$ (III) and $\mathrm{Cr}$ (VI)}

The conditions affecting the sensitivity and selectivity of chromium element on ICP-MS system were optimized including isotopes and other factors such as carrier gas flow, plasma gas flow, nebulizer gas flow, deflector voltage, torch depth, ect. Besides, the conditions impact on retention time and substances separation on liquid chromatography system were also investigated consisting of buffer concentration, mobile phase $\mathrm{pH}$, and mobile phase flow rate.

\subsubsection{Optimizing conditions for sample treatment procedure}

In this study, the factors affecting extraction efficiency were investigated including extraction solvent, as well as sample extraction temperature and time.

\subsubsection{Method validation}

The method was validated with the following parameters: specificity, working calibration curve, method detection limit (MDL), method quantitation limit (MQL), precision and trueness.

\section{RESULTS AND DISCUSSION}

\subsection{Optimizing the conditions for the ICP-MS system}

Chromium has 4 isotopes, of which ${ }^{52} \mathrm{Cr}$ isotope is the most common, accounting for $83.8 \%$. Other isotopes such as ${ }^{53} \mathrm{Cr} 9.5 \%,{ }^{50} \mathrm{Cr} 4.3 \%,{ }^{54} \mathrm{Cr} 2.4 \%$ are less common. Therefore, the ${ }^{52} \mathrm{Cr}$ isotope was chosen to determine $\mathrm{Cr}$ (III) and $\mathrm{Cr}$ (VI). In general, ${ }^{52} \mathrm{Cr}$ isotope may affected by ${ }^{40} \mathrm{Ar} \mathrm{C}, \mathrm{HClO}$ mass isotopes. In this study, the collision cell used helium gas to remove spectral interferences. Other parameters affecting the accuracy, sensitivity and stability of analysis process such as RF power, carrier gas flow, plasma depth, ion lens potential, etc., were automatically optimized on the system (using software and equipment calibration solutions from Perkin Elmer). The optimizing parameters are shown in Table 1.

Table 1. Optimizing parameters for ICP-MS system

\begin{tabular}{lccc}
\hline Parameters & Chosen value & Parameters & Chosen value \\
\hline RF Power & $1250 \mathrm{~W}$ & Nebulizer gas flow & $0.80 \mathrm{~L} / \mathrm{min}$ \\
Carrier gas flow & $1.3 \mathrm{~mL} / \mathrm{min}$ & Sweeps & 20 times \\
Plasma gas flow & $19.0 \mathrm{~L} / \mathrm{min}$ & Replicates & 3 times \\
Deflector voltage & $-11 \mathrm{~V}$ & Mode & $\mathrm{KED}$ \\
Dwell time & $1000 \mathrm{~ms}$ & Cell gas & Helium, $4 \mathrm{~mL} / \mathrm{min}$
\end{tabular}

The above parameters were simultaneously optimized so that both chromium species could reach the high intensity while reducing the background noise. After the automatic optimization, the parameters need to be checked to achieve the corresponding required values. In particular, the sensitivity of the device is mainly based on the response of Indium intensity, the ratio of $\mathrm{CeO} / \mathrm{Ce}$ and $\mathrm{Ce}^{2+} / \mathrm{Ce}$. The actual intensity of the parameters after each daily inspection may varied, but must still be achieved according to the equipment manufacturer testing standards to ensure the stability and sensitivity.

\subsection{Optimizing the conditions for the HPLC system}

\subsubsection{Investigation of EDTA concentration in mobile phase}

In this study, $\mathrm{Cr}$ (III) and $\mathrm{Cr}$ (VI) were separated using reverse phase chromatography with a Hamilton anion exchange column PRP-X100 (5 $\mu \mathrm{m}$ x 4.6 x $150 \mathrm{~mm}$ ), a mobile phase 
simultaneously containing $14 \mathrm{mM} \mathrm{NH}_{4} \mathrm{NO}_{3}$, EDTA salt, $\mathrm{pH}$ of 7.0. However, the concentration of EDTA plays an important role in the complexing ability of $\mathrm{Cr}$ (III), so that it can be separated from $\mathrm{Cr}$ (VI) on the column. Therefore, EDTA concentration was investigated at the levels of $0 \mathrm{mM}, 0.27 \mathrm{mM}, 0.54 \mathrm{mM}, 0.81 \mathrm{mM}$, and $1.08 \mathrm{mM}$. The survey results showed that EDTA concentration in mobile phase was inversely proportional to the retention time and the resolution of analytes. At the concentration of $0.81 \mathrm{mM}$ EDTA, the retention time was shortest and still remained well resolution. Therefore, $0.81 \mathrm{mM}$ EDTA was selected and kept constant in next studies.

\subsubsection{Investigation of $\mathrm{pH}$ mobile phase}

After the appropriate EDTA concentration was selected, the effect of $\mathrm{pH}$ to separative ability of chromium species was investigated. The $\mathrm{pH}$ value of mobile phase was changed from 6.0 to 9.0 with a jump of one unit while the other factors in mobile phase were kept constant in the survey: $0.81 \mathrm{mM}$ EDTA, $14 \mathrm{mM} \mathrm{NH}_{4} \mathrm{NO}_{3}$. The results are shown in chromatograms in Figure 2.
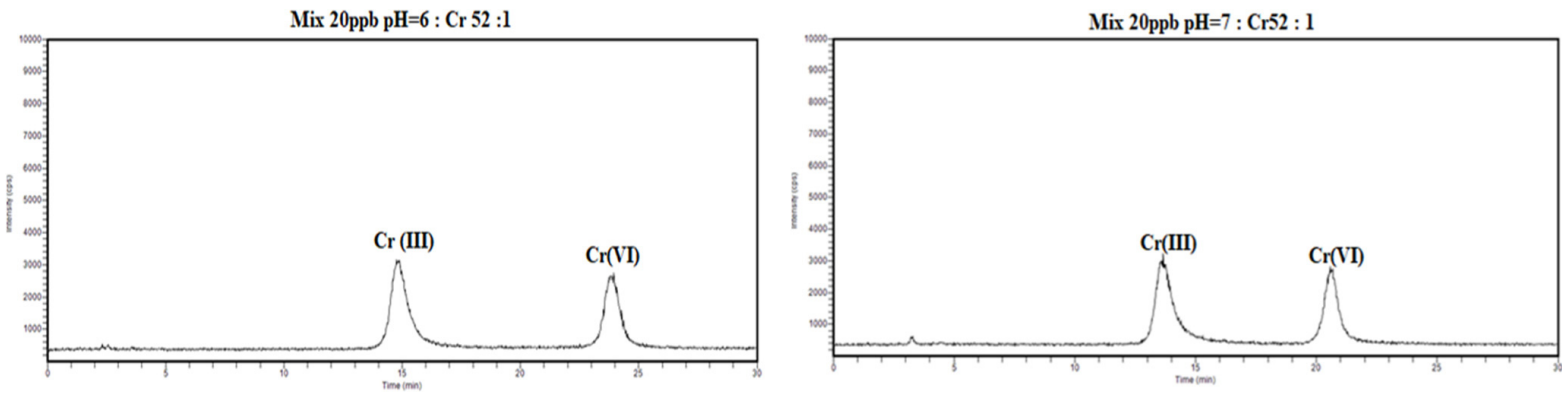

a) $\mathrm{pH}=6.0$

b) $p H=7.0$
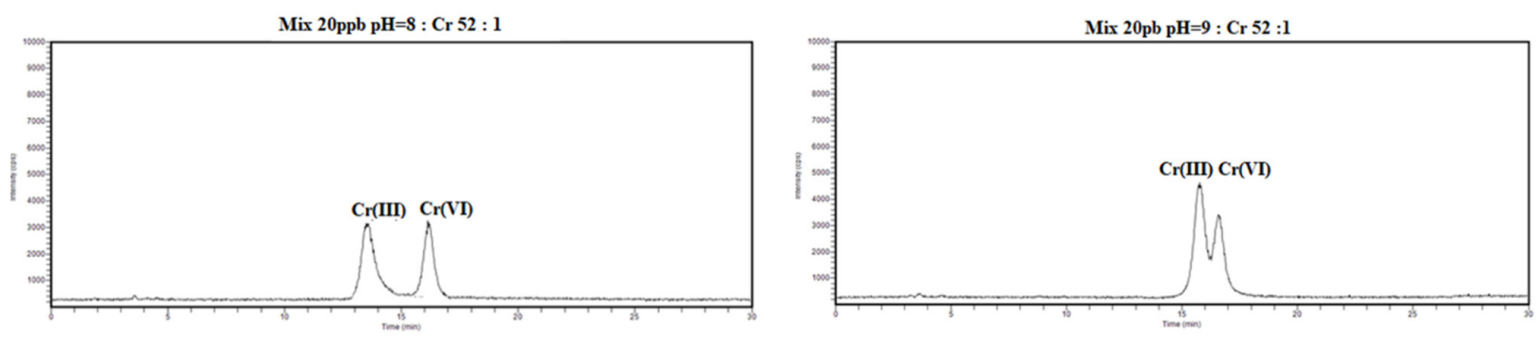

c) $p H=8.0$

d) $p H=9.0$

Figure 2. Chromatograms of Cr (III) and Cr (VI) mixtures of $20 \mathrm{ppb}$

The results in Figure $2 \mathrm{a}-2 \mathrm{~d}$ show that, when the $\mathrm{pH}$ value increases, the retention time and the resolution of analytes decrease. At $\mathrm{pH}$ of 8.0, both chromium species were well separated and eluted within 20 minutes, suitable for quantitative analysis requirements. Therefore, a $\mathrm{pH}$ value of 8.0 was selected for next studies.

\subsubsection{Investigation of mobile phase flow rate}

The mobile phase flow rate was varied from 0.9 to $1.2 \mathrm{~mL} / \mathrm{min}$ with a jump of 0.1 $\mathrm{mL} / \mathrm{min}$. The survey results show that the mobile phase rate was inversely proportional to the retention time of analytes. When the flow rate was changed from 0.9 to $1.2 \mathrm{~mL} / \mathrm{min}$, the retention time of chromium species was gradually decrease by survey steps. However, in order to ensure well separation when they appeared simultaneously in samples matrix as well as the stability of the column, a mobile phase rate of $1.0 \mathrm{~mL} / \mathrm{min}$ was selected for next studies (Figure 3). 


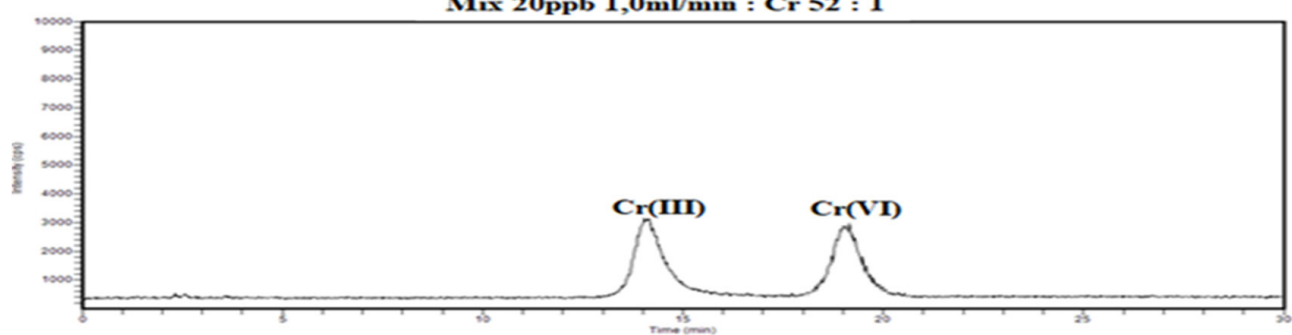

Figure 3. Chromatogram for Cr(III) and Cr(VI) mixtures of $20 \mathrm{ppb}$ at the flow rate of $1.0 \mathrm{~mL} / \mathrm{min}$

\subsection{Sample treatment conditions}

\subsubsection{Investigation of the effects of extraction solvent}

Referring to previous research documents, chromium analysis was conducted mainly on the basis of environmental samples such as water, soil and sediment $[4,6,7,8]$. In this study, several different extraction solvents were selected for investigation with the aim of providing a fast and accurate extraction procedure as well as suitable for laboratory conditions. Besides, it is mostly important that the suitability of solvents to selected column and system conditions. Some of mixed extraction solvents were selected as follows: $50 \mathrm{mM}$ EDTA; 16 mM EDTA, $0.28 \mathrm{M} \mathrm{NH}_{4} \mathrm{NO}_{3}$, $\mathrm{pH}$ of 8.0; $\% \mathrm{NaOH}, 3 \% \mathrm{Na}_{2} \mathrm{CO}_{3}, 0.4 \mathrm{~mol} / \mathrm{L} \mathrm{MgCl} 2 ; 20 \mathrm{mM} \mathrm{NaCl} ; 50 \mathrm{mM}$ $\mathrm{KH}_{2} \mathrm{PO}_{4}, 5 \mathrm{mM} \mathrm{Na} \mathrm{HPO}_{4}$. Surveys were conducted on functional food samples with known total chromium content (supplemented in the species of $\mathrm{Cr}$ (III) picolinate) when analyzed using ICP-MS system. Other extraction conditions were kept constant such as: 60 minutes extraction time, $80^{\circ} \mathrm{C}$ extraction temperature. The results are shown in Figure 4.

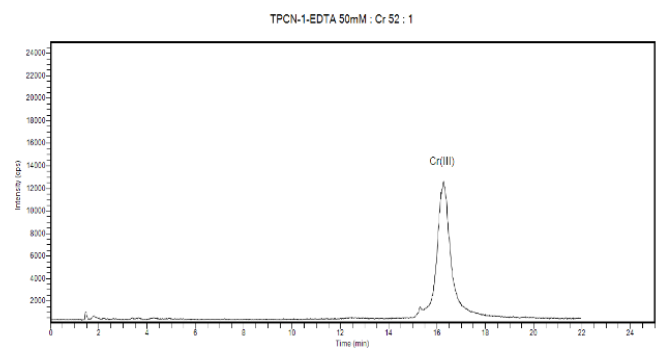

a) Extraction solvent of $50 \mathrm{mM}$ EDTA

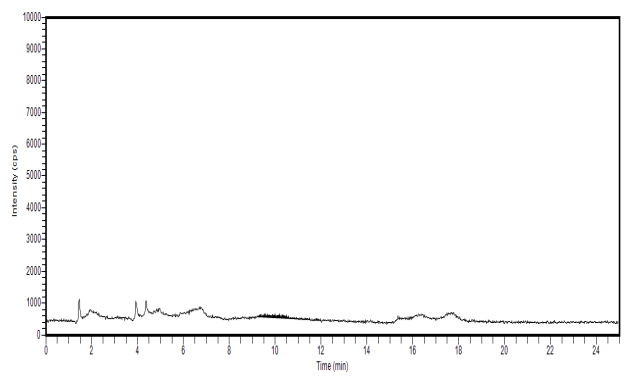

c) Extraction solvent of $2 \% \mathrm{NaOH}$, and $3 \% \mathrm{Na}_{2} \mathrm{CO}_{3}$

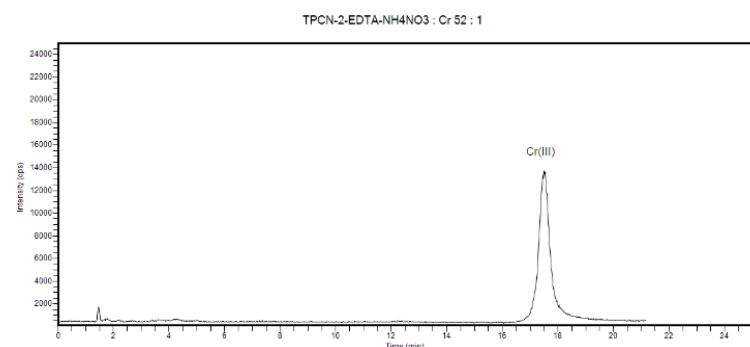

b) Extraction solvent of $16 \mathrm{mM}$ EDTA, $0.28 \mathrm{M} \mathrm{NH}_{4} \mathrm{NO}_{3}$, and $\mathrm{pH} 8.0$

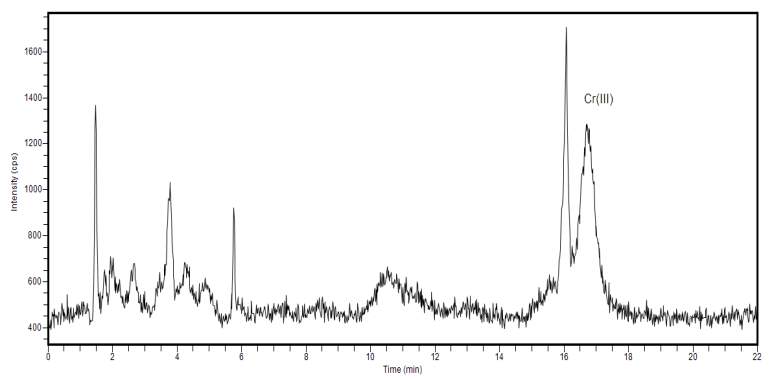

d) Extraction solvent of $5 \mathrm{mM} \mathrm{Na}_{2} \mathrm{HPO}_{4}$ and $50 \mathrm{mM} \mathrm{KH}_{2} \mathrm{PO}_{4}$

Figure 4. Chromatograms for Cr (III) in different extraction solvents

The results in Figure $4 \mathrm{a}-4 \mathrm{~d}$ show the appearance of $\mathrm{Cr}$ (III) peak when the extraction was conducted with $50 \mathrm{mM}$ EDTA solvent or mixed solvent of $16 \mathrm{mM}$ EDTA, $0.28 \mathrm{M} \mathrm{NH}_{4} \mathrm{NO}_{3}$, 
$\mathrm{pH}$ of 8.0. These solvents contain EDTA salt which is able to form complexes with metal ions. Thus, chromium can be extracted easily from samples. The extraction of Cr (III) is perfectly suited to the nature of the sample matrix. The use of other mixed solvents under the same conditions hardly extracts chromium species (Figure 4c - 4d). Therefore, a mixed solvent EDTA of $16 \mathrm{mM}, 0.28 \mathrm{M} \mathrm{NH}_{4} \mathrm{NO}_{3}$ and $\mathrm{pH}$ of 8.0 was selected to investigate next conditions (Figure $4 \mathrm{~b}$ ).

\subsubsection{Investigation of the effects of extraction time and temperature}

After selected the extraction solvent, other factors were investigated to get the best conditions for ultrasonic extraction including extraction time and temperature. The extraction time was studied in about 30 - $70 \mathrm{~min}$, while the extraction temperature was studied in the range of $50-80^{\circ} \mathrm{C}$. The best recovery was found at $60 \mathrm{~min}$ and $80^{\circ} \mathrm{C}$ respectively. Investigation of the effects of extraction time and temperature are shown in Figure 5.
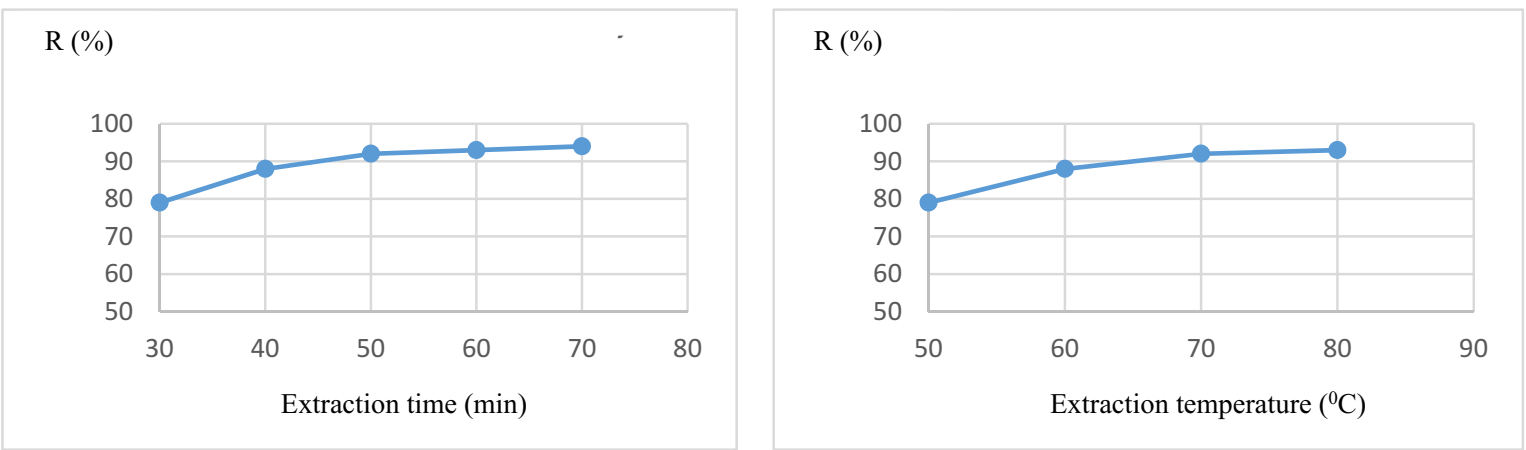

Figure 5. Investigation for the effects of extraction time and temperature

After the conditions for analyzing and extracting chromium species are investigated and optimized, the procedure of sample treatment is summarized in Figure 6.

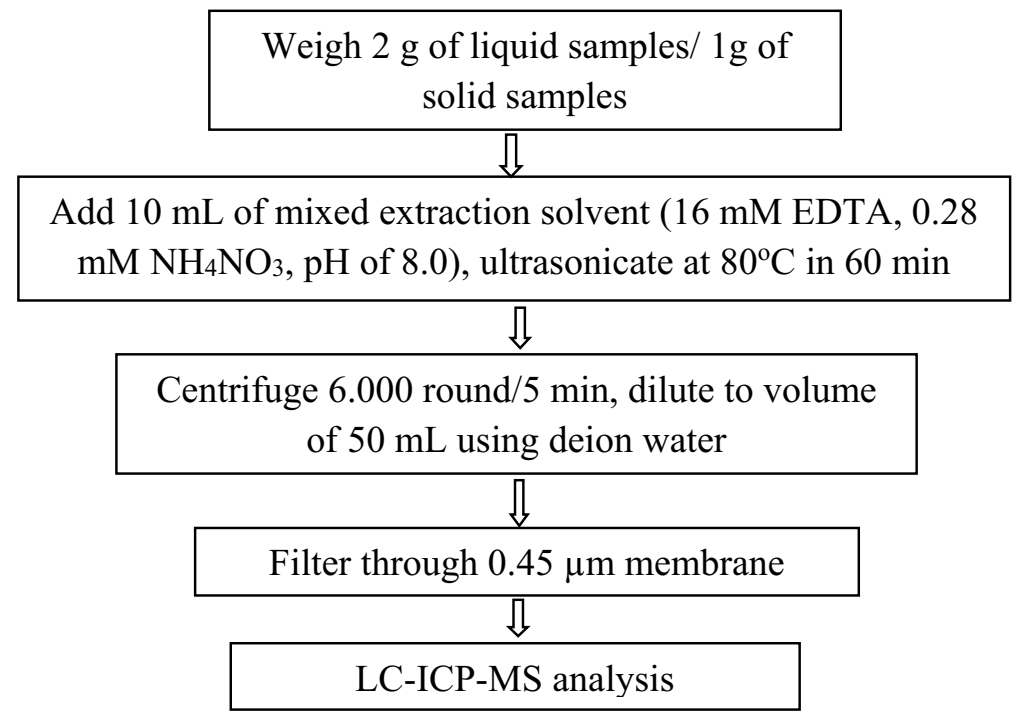

Figure 6. The procedure of analysis of chromium species in functional food samples This procedure is applied to conduct method validation and analysis of real samples.

\subsection{Method validation}

Blank samples and spiked blank samples at the level of analytes as with standard solutions 
were analyzed to evaluate the specificity. The chromatograms of blank samples did not indicate the peak of chromium as in the case of spiked blank samples and standard solutions. This demonstrates that the method has good specificity.

The calibration curve for both of $\mathrm{Cr}$ (III) and $\mathrm{Cr}$ (VI) species was established in the range of $2-100 \mu \mathrm{g} / \mathrm{L}$ with a correlation coefficient $\mathrm{R}^{2} \geq 0.995$ in accordance with the quantitative requirements.

The results of evaluating the calibration curve equation, method detection limit, method quantitation limit (MQL), repeatability (RSDr), recovery (R \%), measurement uncertainty (U \%) of analytes are summarized in Table 2.

Table 2. The results of evaluating method of analysis

\begin{tabular}{|c|c|c|c|c|c|c|c|}
\hline Substances & $\begin{array}{c}\text { Calibration } \\
\text { curve }\end{array}$ & $\begin{array}{c}\text { Correlation } \\
\text { coefficient } R^{2}\end{array}$ & $\begin{array}{c}M D L \\
(\mu g / k g)\end{array}$ & $\begin{array}{c}M Q L \\
(\mu g / k g)\end{array}$ & $R S D r(\%)$ & $R(\%)$ & $U(\%)$ \\
\hline $\operatorname{Cr}(I I I)$ & $\begin{array}{l}y=16.229 \\
+5001.1 x\end{array}$ & 0.9995 & 20 & 66 & $\begin{array}{c}1.96- \\
6.88\end{array}$ & $88.0-103$ & 15 \\
\hline $\operatorname{Cr}(V I)$ & $\begin{array}{c}y=-3027.6 \\
+5803.5 x\end{array}$ & 0.9998 & 10 & 33 & 7.78 & $89.3-106$ & 20 \\
\hline
\end{tabular}

The method was validated with the parameters meeting the AOAC performance requirements, showing that the method was completely suitable for determining $\mathrm{Cr}$ (III) and $\mathrm{Cr}$ (VI) species in functional foods.

\subsection{Analysis of real samples}

Some functional foods samples of syrup, nugget and capsule forms collected in Hanoi city were analyzed. The results are summarized in Table 3.

Table 3. The results of analysis of $\mathrm{Cr}(\mathrm{III})$ and $\mathrm{Cr}(\mathrm{VI})$ in some functional food samples

\begin{tabular}{|c|c|c|c|c|}
\hline \multirow{2}{*}{ No. } & \multirow{2}{*}{ Types } & \multicolumn{2}{|c|}{ Cr species } & \multirow{2}{*}{$\begin{array}{c}\text { Cr content on } \\
\text { labels }\end{array}$} \\
\hline & & Cr (III) & $C r(V I)$ & \\
\hline M1 & Syrup & ND & ND & NA \\
\hline M2 & Syrup & ND & ND & NA \\
\hline M3 & Syrup & ND & ND & NA \\
\hline M4 & Soft capsules & $65.4 \pm 9.81 \mu \mathrm{g} /$ tablet & ND & $67 \mu \mathrm{g} /$ tablet \\
\hline M5 & Hard Capsules & $195 \pm 29.3 \mu \mathrm{g} /$ tablet & ND & $200 \mu \mathrm{g} /$ tablet \\
\hline M6 & Hard Capsules & $85.0 \pm 12.7 \mu \mathrm{g} /$ tablet & ND & $90 \mu \mathrm{g} /$ tablet \\
\hline M7 & Nugget & $<66 \mu \mathrm{g} / \mathrm{kg}$ & ND & NA \\
\hline M8 & Nugget & ND & ND & NA \\
\hline
\end{tabular}

*ND - Not detected: the content is less than the value of method detection limit

*NA - Not applicable: there is not information on the labels

The results in Table 3 show that samples of syrup and nugget without information for chromium on labels showed low levels of $\mathrm{Cr}$ (III) (less than method detection limit) or not detected both of chromium species. Some functional foods supplemented with chromium (form of $\mathrm{Cr}$ (III) picolinate) in capsules forms which have the content of $\mathrm{Cr}$ (III) in the range of 
65.4 - $195.0 \mu \mathrm{g}$ per tablet. These content levels reached 94 - 97\% compared to the produc announcement records in the range of $67.0 \mu \mathrm{g}$ to $200 \mu \mathrm{g}$ per tablet. Moreover, all analyzed samples did not detect the appearance of $\mathrm{Cr}$ (VI), show that the products are manufactured from safe materials as well as processed and stored properly. Preliminary research shows the safety of chromium fortified in several products on the market in Ha Noi city. Figure 7 illustrated a chromatogram analyzing a functional food sample in soft capsule form (M4).

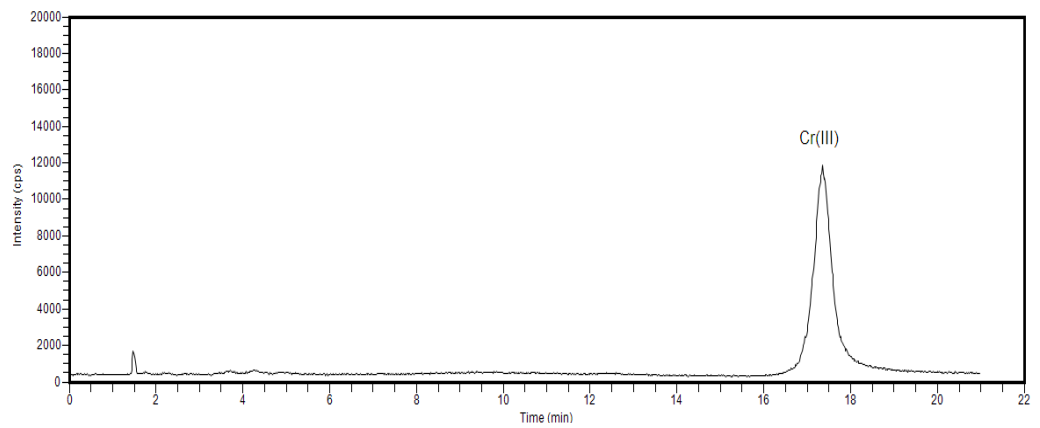

Figure 7. Chromatogram for chromium species analysis in a functional food sample (M4)

\section{CONCLUSION}

In this study, the method for analyzing chromium form content in functional foods by LC-ICP-MS was optimized for the analytical conditions and investigated the factors affecting sample treatment procedure. The validated parameters were in compliance with the requirements of the AOAC standard. The method was applied to determine $\mathrm{Cr}$ (III) and $\mathrm{Cr}$ (VI) contents in several functional food samples. Chromium (III) was found in 3 of 8 products with the content meeting the declaration on labels, and not detected the appearance of toxic Cr (VI) in survey samples. This study also contributes to clarify the existence of chromium in functional food samples. However, the studies should be carried out on larger sample sizes, especially low-level supplements or more complex ingredients such as powdered milk in order to promptly issue risk warnings affecting consumers' health.

\section{REFERENCES}

[1] D. G. Barceloux, “Chromium,” Clinical Toxicology, vol. 3, no.2, pp. 173-194,1999.

[2] J. Kotaś, Z. Stasicka, "Chromium occurrence in the environment and methods of its speciation,” Environmental Pollution, vol. 107, no. 3, pp. 263-283, 2000.

[3] J. Emsley, "Chromium", Nature's Building Blocks: An A-Z Guide to the Elements, Oxford, England, UK: Oxford University Press, pp. 495-498, 2001.

[4] H. Gurleyuk, "Determination of chromium (III) and chromium (VI) using suppressed ion chromatography inductively coupled plasma mass spectrometry", Journal of Analytical Atomic Spectrometry, vol. 16, no. 9, pp. 926-930, 2001.

[5] R. A. Gonzalez, K. Ndung'u, AR. Flegal, "Natural Occurrence of Hexavalent Chromium in the Aromas Red Sands Aquifer, California”, Environmental Science and Technology, vol. 39, no. 15, pp. 5505-5511, 2005.

[6] S. Catalani, J. Fostinelli, M. E. Gilberti, P. Apostoli, "Application of a metal free high performance liquid chromatography with inductively coupled plasma mass spectrometry (HPLC-ICP-MS) for the determination of chromium species in drinking and tap water", International Journal of Mass Spectrometry, vol. 387, pp. 31-37, 2015. 
[7] H. Ernstberger, K. Neubauer, "Chromium Speciation in Water by HPLC/ICP-MS", Perkin Elmer Appl. Note, 2015.

[8] L. Ya-An, J. Shiuh-Jen, A. C. Sahayam, H. Yeou-Lih, "Speciation of chromium in edible animal oils after microwave extraction and liquid chromatography inductively coupled plasma mass spectrometry", Microchemical Journal, vol. 28, pp. 274-278, 2016.

\title{
Xác định đổng thời hàm Iượng dạng Cr (III) và Cr (VI) trong thực phẩm chức năng bằng phương pháp LC-ICP-MS
}

\author{
Phạm Công Hiếu ${ }^{1}$, Lê Văn Hà ${ }^{1}$, Nguyễn Minh Châu ${ }^{1}$, Lũ̃ Thị Minh Hiền ${ }^{1}$ \\ Đinh Viết Chiến ${ }^{1}$, Nguyễn Trung Hiếu ${ }^{2}$, Nguyễn Văn $\mathbf{R i}^{2}$ \\ ${ }^{1}$ Viện Kiểm nghiệm an toàn vệ sinh thực phẩm Quốc gia \\ ${ }^{2}$ Truò̀ng Đại học khoa học tự nhiên, Đại học Quốc gia Hà Nội
}

\section{Tóm tắt}

Crom thường được bổ sung trong một số loại thực phẩm chức năng nhằm hỗ trợ điều trị bệnh tiểu đường hay trong các sản phẩm sữa bổ sung vi chất. Trong tự nhiên Crom tồn tại các dạng oxi hóa với độc tính khác nhau, do đó cần thiết phải xác định các dạng Crom để đánh giá chính xác mối nguy an toàn thực phẩm. Trong nghiên cứu này, dạng $\mathrm{Cr}(\mathrm{III})$ và $\mathrm{Cr}(\mathrm{VI})$ được xác định bằng phương pháp sắc ký lỏng ghép nối khối phổ plasma cao tần cảm ứng (LC-ICPMS) sử dụng chế độ va chạm (collision cell). Các thông số quan trọng được tối ưu như: nồng độ chất tạo phức, ảnh hưởng của $\mathrm{pH}$, tốc độ dòng pha động, dung môi chiết, nhiệt độ và thời gian chiết. Phương pháp cho thấy có độ đặc hiệu tốt, giới hạn phát hiện của $\mathrm{Cr}$ (III) là $20 \mu \mathrm{g} / \mathrm{kg}$, $\mathrm{Cr}(\mathrm{VI})$ là $10 \mu \mathrm{g} / \mathrm{kg}$. Độ lệch chuẩn tương đối lặp lại của $\mathrm{Cr}$ (III) là $1,96 \%$ và của $\mathrm{Cr}(\mathrm{VI})$ là $7,78 \%$. Độ thu hồi của $\mathrm{Cr}$ (III) và $\mathrm{Cr}(\mathrm{VI})$ tại khoảng nồng độ $1,0 \mathrm{mg} / \mathrm{kg}$ lần lượt trong khoảng 88,0 - 103\% và $89,3-96,7 \%$, hoàn toàn đáp ứng theo quy định của $\mathrm{AOAC}$. Phương pháp được ứng dụng phân tích dạng $\mathrm{Cr}$ (III) và $\mathrm{Cr}(\mathrm{VI})$ trong một số mẫu thực phẩm chức năng trên thị trường, bước đầu cho thấy các mẫu có hàm lượng $\mathrm{Cr}$ (III) phù hợp với công bố trên nhãn sản phẩm và đều không phát hiện dạng $\mathrm{Cr}(\mathrm{VI})$ độc hại.

Tù̀ khóa: Các dạng Crom, Cr (III), Cr (VI), thực phẩm chức năng, LC-ICP-MS. 